\title{
Deskripsi Jenis-Jenis Kontaminan Dari Kultur Kalus Catharanthus roseus (L.) G. Don
}

\author{
Kristina M. Oratmanguna, Dingse Pandianganaa*, Febby E. Kandoua* \\ aJurusan Biologi, FMIPA, Unsrat, Manado
}

\begin{tabular}{l}
\hline K A T A K U N C I \\
\hline Kontaminan, \\
Catharanthus roseus, \\
Kultur, \\
Kalus.
\end{tabular}

\begin{abstract}
A B S T R A K
Penelitian deskripsi jenis-jenis kontaminan dari kultur kalus Catharanthus roseus telah dilakukan. Penelitian ini bertujuan untuk mendeskripsikan jenis-jenis kontaminan yang terdapat pada kultur kalus C.roseus. Penelitian ini dilaksanakan dua tahap. Tahap pertama dilakukan kultur kalus $C$. roseus. Kultur kalus menggunakan media MS (Murashige dan Skoog) dengan zpt 2,4 D $2 \mathrm{mg} / \mathrm{L}$ dan kinetin 0,2 mg/L. Tahap kedua dilakukan pengamatan kultur kalus yang mengalami kontaminasi. Kontaminan-kontaminan yang sama secara kasat mata dikelompokan menjadi satu kelompok. Setiap kelompok yang sama diamati lebih lanjut dibawah mikroskop. Penentuan jenis kontaminan dibandingkan dengan morfologi dari Pustaka (rujukan). Pengamatan kontaminan dilakukan mulai dari pembuatan media, inokulasi, subkultur kalus C.roseus. Pengamatan dilakukan dengan 3 botol kontaminan dari setiap kelompok. Hasil yang diperoleh adalah kontaminan kultur kalus C. roseus sekitar 40 $\%$. Jenis kontaminan yang diamati umumnya golongan jamur. Jenis-jenis kontaminan kultur kalus C. roseus adalah Rhizopus, Mucor, Aspergillus, dan Sacharomyces.
\end{abstract}

K E Y W O R D S

Cotaminants,

Catharanthus roseus,

Callus,

Culture
A B S T R A C T

Research description of the types of contaminant for cultured callus Catharanthus roseus has been done. This research aimed describe the types of contaminant found in the cultured kalus $C$. roseus. This research is carried out in two stages. The first stage in callus culture $C$. roseus using media MS (Murashige and Skoog) with zpt 2,4 D mg/L and kinetin 0,2 $\mathrm{mg} / \mathrm{L}$. The second stage in the observation of contaminated callus culture. The same of contaminants are visible into one group. Each of the same group was observed further under a microscope. Determining the types of contaminant in comparison with reference from the literature. Observation are starting from media or inoculation, subcallus culture C. roseus. Observation done by taking 3 bottles of contaminat from each group then observed for 7 days. The result obtained are culture contaminants $C$. roseus about $40 \%$. The types of contaminant observed are generally of fungi. The types of contaminant callus culture C. roseus are Rhizopus, Mucor, Aspergillus, and Sacharomyces.
TERSEDIA ONLINE

1 Februari 2017

\section{Pendahuluan}

Kultur jaringan atau kultur in vitro atau tissue culture adalah suatu teknik untuk mengisolasi sel, jaringan, dan organ kemudian menumbuhkan bagian tersebut pada media buatan yang mengandung kaya nutrisi dan zat pengatur tumbuh pada kondisi aseptik, sehingga bagian-bagian tersebut dapat memperbanyak diri dan berenegerasi menjadi tumbuhan sempurna kembali. Namun, kontaminasi oleh mikroba merupakan salah satu masalah serius dalam kultur in vitro tanaman (Leifert dan Cassells, 2001). Kontaminasi tersebut merupakan penyebab utama hilangnya kultur tanaman. Upaya untuk meningkatkan skala 
produksi (scaling up) kultur in vitro seringkali terhambat oleh adanya kontaminasi mikroba.

Proses kultur jaringan membutuhkan kondisi yang steril. Kalau kondisi terkontaminasi, kultur akan mati atau rusak. Komponen paling rentan terhadap kontaminasi mikroorganisme adalah media tumbuh dan eksplan. Gunawan (1987), media kultur jaringan merupakan media yang sangat mendukung bagi pertumbuhan jamur dan bakteri. Mikrooganisme akan tumbuh dengan cepat dan akan menutupi permukaan media dan eksplan yang ditanam. Di samping itu, mikrooganisme akan menyerang eksplan melalui luka-luka akibat pemotongan dan penanganan waktu sterilisasi sehingga mengakibatkan jaringan eksplan. Eksplan yang terkontaminasi akan menunjukkan gejala berwarna putih, biru atau krem yang disebabkan jamur dan bakteri.

Media tumbuh dan eksplan dapat terkontaminasi oleh mikrooganisme karena keduaduanya dapat berfungsi sebagai subsrat yang baik bagi pertumbuhan mikroorganisme termasuk bakteri (Doods dan Roberts, 1983) dan jamur (Gunawan, 1987).

Kultur jaringan memerlukan kecermatan yang tinggi dan keadaan yang aseptik baik tempat kerja, alat-alat dan bahan-bahan serta tangan orang yang mengerjakannya, sebab dapat terjadi kontaminasi dengan mikroorganisme antara lain bakteri dan jamur yang akan nampak berupa koloni-koloni di permukaan medium. Pandiangan (2003), mengatakan kontaminasi dapat terjadi dari eksplan baik eksternal maupun internal, mikroorganisme yang masuk kedalam media, botol kultur atau alatalat tanam yang kurang steril, ruang kerja dan kultur yang kotor (mengandung spora di udara ruangan laboratorium) dan kecerobohan dalam pelaksanaan. Untuk membuat kondisi aseptik dapat dipakai pemanasan autoklaf, desinfektan atau lampu ultraviolet, sehingga mikroba-mikroba pengganggu dapat dimatikan.

Pengamatan dari berbagai macam hasil kultur jaringan, banyak media kultur dan eksplan yang terkontaminasi, dengan menunjukkan koloni yang berwarna putih atau biru untuk jamur dan menampakkan gejala busuk untuk bakteri. Menurut Gunawan (1987), untuk mendeskripsikan bakteri dan jamur diawali dengan pengamatan morfologi. Berdasarkan uraian tersebut, perlu untuk mengetahui jenis-jenis bakteri dan jamur yang terdapat pada medium kultur jaringan dengan eksplan yang terkontaminasi.

\section{Material dan Metode}

Penelitian ini dilaksanakan di Laboratorium Bioteknologi Fakultas Pertanian Universitas Sam Ratulangi Manado untuk kultur kalus Catharanthus roseus. Pengamatan deskripsi bakteri dan jamur dilaksanakan di Laboratorium Mikrobiologi Fakultas Matematika dan IImu Pengetahuan Alam Universitas Sam Ratulangi Manado. Waktu pelaksanaan penelitian (Oktober-November 2016).
Prosedur dalam penelitian ini meliputi beberapa tahap yaitu, Sterilisasi Alat, Media dan Bahan. Persiapan dan pembuatan media, Sterilisasi Eksplan atau Bahan Tanaman, Inokulasi eksplan pada media, dan Cara Pendeskripsian Kontaminan.

Sterilisasi Alat, Media dan Bahan

Sterilisasi alat, media dan bahan mengikuti metode Pandiangan et al (2006). Alat-alat dan botol yang dicuci sampai bersih dengan menggunakan detergen, setelah selesai dicuci cawan petri dibungkus dan juga alat-alat lainnya dengan kertas atau aliminium foil. Kemudian autoklaf diisi dengan air sampai batas raknya setelah itu masukkan botol-botol yang sudah bersih kedalam autoklaf beserta alat-alat lain. Autoklaf ditutup. Tekanannya mencapai tekanan $15 \mathrm{lb} / \mathrm{in}^{2}$. Listrik dihidupkan dan tunggu sampai tekanan mencapai tekanan yang dianjurkan. Setelah mencapai tekanan, autoklaf dimatikan dan tunggu sampai suhu turun. Botol dan alat-alat lainnya dikeluarkan kemudian dikeringkan didalam oven atau di ruang transfer. Setelah kering maka sudah dapat digunakan. Setelah itu, media yang akan disterilkan diganti dengan akuades untuk dapat dimanfaatkan untuk sterilisasi eksplan. Kemudian botol-botol diisi dengan akuades yang steril sekitar 10-15 mL tergantung besar botol (setinggi $1 \mathrm{~mL}$ ). Botol ditutup dengan aluminuim foil dan dimasukkan ke dalam autoklaf (Pandiangan, 2011).

\section{Persiapan dan pembuatan media}

Pembuatan media mengikuti metode Pandiangan et al (2011). Perhitungan dilakukan seberapa banyak media yang dibuat. Media dibuat dalam 1 liter, semua stok media disiapkan di atas meja kerja. Kemudian wadah untuk campuran (digunakan beaker glass $1000 \mathrm{~mL}$ dari pirex), dilakukan pemanasan, diisikan air di wadah tersebut sekitar $100 \mathrm{~mL}$. Setelah itu semua stok dipipet atau dicampurkan satu per satu secara berurutan mulai dari A sampai seterusnya. Agar ditimbang sebanyak $8 \mathrm{gr}$, dan gula $30 \mathrm{gr}$. Gula dimasukkan dalam erlenmeyer dan dilarutkan dengan akuades sekitar $150 \mathrm{~mL}$, diaduk hingga larut kemudian dimasukkan ke campuran. Setelah itu menyaring gula dengan saringan (kain kasa). Kemudian campuran diaduk kembali. Akuades ditambahkan sehingga volume campuran $1000 \mathrm{~mL}$. Sebelum media dipanaskan $\mathrm{pH}$ media diukur terlebih dahulu yaitu sekitar 5,5-5,8. Media dipanaskan dalam hotplate yang dilengkapi dengan stirrer, kemudian ditambahkan agar dan diaduk secara perlahan. Botol kultur yang sudah disterilkan disiapkan sekitar 50 botol dan potong-potong aluminium foil persegi sesuai ukuran mulut botol kultur. Media diisikan ke dalam botol kultur kemudian ditutup dengan aluminium foil dan Sterilisasi dilakukan pada autoklaf $15 \mathrm{lb} /$ inc $^{2}$ (Pandiangan, 2009).

\section{Sterilisasi Eksplan atau Bahan Tanaman}

Eksplan disterilkan mengikuti metode Pandiangan et al, (2006). Kotoran dibersihkan 
dengan air. Bagian yang akan disterilkan dipotong dan dibuat larutan pemutih sekitar $70 \%$. Akuades steril $1000 \mathrm{~mL}$ disiapkan, kemudian scalpel dan alkohol $95 \% 150 \mathrm{~mL}$ untuk membakar alat-alat pemotong, aluminium foil steril dan kapas pembersih yang diolesi alkohol, cawan petri yang dibungkus dan media yang sudah steril. Pemutih dimasukkan ke dalam eksplan dan di goyanggoyang tunggu hingga 15 menit kemudian tuangkan dan bilas dengan akuades. Lakukan beberapa kali sehingga bersih. Potongan eksplan dibuat sesuai anjuran (sekitar 0,5 $\mathrm{mm} \times 1 \mathrm{~mm}$ ), kemudian masukkan dalam media yang sudah disediakan (Pandiangan, 2003).

Inokulasi eksplan pada media

Proses inokulasi eksplan dapat dipakai dengan mengikuti metode Pandiangan et al (2006). Pinset dan scalpel serta pisaunya disterilkan dalam alkohol $95 \%$ yang sebelum dipakai dibakar pada nyala api bunsen dan didinginkan sedikit baru dipakai. Eksplan yang sudah steril diambil 1 helai daun (dengan pinset steril). Daun dipotong-potong sekitar 0,5 $\mathrm{mm} \times 0,5 \mathrm{~mm}$, dan diusahakan tulang daunnya yang besar dikeluarkan satu daun dapat menghasilkan 5 atau 6 potongan daun. Cara tersebut dilakukan berulang-ulang sampai media sebanyak 50 botol habis. Kemudian diinkubasi dalam ruang kultur untuk induksi kalus. Hasil inokulasi dikeluarkan dari laminar dan ditempatkan dalam ruang inkubasi, suhu ruangan diatur sekitar $25^{\circ} \mathrm{C}$ dan pencahayaan yang cukup dan diberi label pada pekerjaan yaitu waktu dikultur, jenis media, dan jenis eksplan.

Cara Pendeskripsian Kontaminan

Kontaminan diambil tiga botol kultur kalus Catharanthus roseus yang disimpan pada ruang kultur. Kemudian diamati secara kasat mata.Untuk membedakan bakteri dan jamur mengunakan referensi Lay (1994) dan Bonang (1982), yaitu dengan mengamati morfologinya.

Morfologi bakteri dengan ciri-ciri yang diamati yaitu besar kecilnya koloni, bentuk koloni, kenaikan permukaan, halus kasarnya permukaan, wajah permukaan, warna koloni, kepekatan untuk lebih jelas dapat dilihat pada Tabel 1.

Morfologi jamur dengan ciri-ciri yang diamati yaitu hifa bersekat atau tidak bersekat, miselium terang atau keruh, miselium berwarna atau tidak, memproduksi spora, warna spora, tangkai spora sederhana atau bercabang, struktur spesifik: stolon, rhizoid, foot cell/ sel kaki dapat dilihat pada Tabel 2.

Setelah kultur terkontaminasi, kemudian kontaminan diamati sampai hari ke-7 secara kasat mata di dalam botol kultur. Setelah pengamatan kultur terkontaminasi dilakukan selama 7 , kemudian diamati dibawah mikroskop cahaya dengan mengambil sebagian (cuplikan) kontaminan. Pengamatan dilakukan seperti warna spora, warna miselium, propusi spora, ada tidaknya sekat miselium, tangkai spora dan struktur spesifik lainnya.

\section{Hasil dan Pembahasan}

Hasil pengamatan selama 7 hari kultur diperoleh 20 botol kultur kalus yang mengalami kontaminasi dari 50 botol kultur kalus. Dari hasil tersebut diperoleh persentasi kontaminasi kultur kalus Catharanthus roseus adalah 20/50 x 100\% = $40 \%$. Pada pengamatan yang dilakukan eksplan yang terkontaminasi menunjukkan gejala berwarna seperti berwarna putih,coklat kehitaman, yang disebabkan jamur. Media tumbuh dan eksplan dapat terkontaminasi oleh jamur karenadapat berfungsi sebagai substrat yang baik bagi pertumbuhan.

Pengamatan pada kelompok I Pada hari 1 dan hari ke 2 pada botol 1,2, dan 3 media tidak berubah atau belum terkontaminasi, hari ke 3 pada botol 1 muncul titik putih pada media, pada botol 2 terlihat hifa putih dipinggir eksplan, kemudian pada botol 3 terlihat hifa putih menyerupai rambut halus dipinggir eksplan C. roseus, hari ke 4 pada botol 1 titik koloni semakin besar, juga pada botol 2 dan botol 3 titik putih koloni semakin besar, hari ke 5 pada botol 1,2, dan 3 koloni semakin memenuhi botol kultur dan eksplan, hari ke 6 pada botol 1,2 dan botol 3 hifa berwarna putih sampai kelabu hitam dan sudah menghasilkan spora, hari ke 7 terdapat spora pada sekitar kontaminan.

Tabel 1. Pengamatan Mikroskop Kontaminan Kelompok I dari Pengamatan Morfologi yang sama.

\begin{tabular}{|ll|c|}
\hline \multicolumn{2}{|c|}{ Hasil Deskripsi } \\
\hline \multicolumn{2}{|c|}{ Ciri-Ciri Morfologi } & Kontaminan \\
\hline 1. & Warna sporangium & Hitam \\
\hline 2. & $\begin{array}{l}\text { Miselium terang atau } \\
\text { keruh }\end{array}$ & Terang \\
\hline 3. & $\begin{array}{l}\text { Miselium berwarna atau } \\
\text { tidak }\end{array}$ & Berwarna \\
\hline 4. & Memproduksi spora & Ada spora \\
\hline 5. & $\begin{array}{l}\text { Hifa bersekat atau tidak } \\
\text { bersekat }\end{array}$ & Tidak bersekat \\
\hline 6. & $\begin{array}{l}\text { Tangkai spora sederhana } \\
\text { atau bercabang }\end{array}$ & Sederhana \\
7. & $\begin{array}{l}\text { Struktur spesifik: stolon, } \\
\text { rhizoid, foot cell/sel kaki }\end{array}$ & Rhizoid \\
\hline
\end{tabular}

Berdasarkan pengamatan pada kelompok I dari pengamatan morfologi yang sama, diambil salah satu botol kontaminan dari ke 3 botol dan dilakukan pengamatan pada mikroskop , karena warna sporangium berwarna kelabu hitam, miselium terang dan berwarna, memproduksi spora, kemudian hifanya tidak bersekat/nonsepta, tangkai spora sederhana dan ada rhizoid. Dari pengamatan pada kelompok I maka termasuk ciri deskripsi dari Rhizopus.Kontaminan kelompok pertama yang ditemukan adalah Rhizopusdan termasuk kelas Zigomycetes (Tortora et al., 2001). 


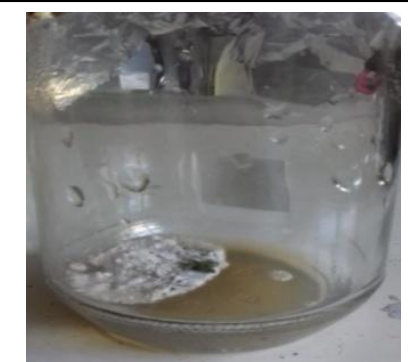

Gambar 1. Hasil Pengamatan Kontaminan pada Kelompok I.

Pengamatan yang dilakukan pada kontaminan kelompok II pada hari 1 dan hari ke 2 belum terkontaminasi pada masing-masing botol yaitu pada botol 1,2 , dan 3 , hari ke 3 pada botol 1 ada hifa pada media kultur berwarna putih, botol 2 terdapat bintik berwarna putih dan berhifa pada permukaan eksplan, botol 3 ada hifa berwarna putih pada media, hari ke 4 pada botol 1 hifa semakin banyak dan menutupi media kontaminan berwarna putih, botol 2 kontaminan berwarna putih menutupi media, botol ke 3 hifa semakin banyak dan kontaminan berwarna putih di permukaan media,hari ke 5 pada botol 1 hifa dan sporangiosfor nampak menonjol ke permukaan seperti jarum pentul dan mengandung sporangium dalam jumlah sedikit, botol 2 sporangiosfor nampak menonjol ke permukaan hifa dan spora masih sedikit, botol ke 3 hifa dan sporangium masih sedikit, hari ke 6 pada botol 1 hifa yang nampak seperti benang putih dan sporangium semakin banyak, botol 2 kontaminan berwarna putih dan menghasilkan spora, botol 3 hifa dan sporangium sudah mulai banyak menutupi kultur, hari ke 7 pada botol 1 kontaminan berwarna putih dan terdapat sporangium menutupi permukaan media, botol 2 kontaminan berwarna putih dan memenuhi semua permukaan kultur, botol 3 hifa seperti benang putih sudah banyak memenuhi botol.

Tabel 2. Pengamatan Mikroskop Kontaminan Kelompok II dari Pengamatan Morfologi yang Sama.

\begin{tabular}{|ll|c|}
\hline \multicolumn{2}{|c|}{ Hasil Deskripsi } \\
\hline \multicolumn{2}{|c|}{ Ciri-Ciri Morfologi } & $\begin{array}{c}\text { Kontaminan } \\
\text { Jamur }\end{array}$ \\
\hline 1. & Warna sporangium & Putih \\
\hline 2. & $\begin{array}{l}\text { Miselium terang atau } \\
\text { keruh }\end{array}$ & Terang \\
\hline 3. & $\begin{array}{l}\text { Miselium berwarna } \\
\text { atau tidak }\end{array}$ & Berwarna \\
\hline 4. & $\begin{array}{l}\text { Memproduksi spora } \\
\text { 5. }\end{array}$ & Ada bersekat atau \\
tidak bersekat & Tidak bersekat \\
\hline 6. & $\begin{array}{l}\text { Tangkai spora } \\
\text { sederhana atau } \\
\text { bercabang }\end{array}$ & Sederhana \\
\hline 7. $\begin{array}{l}\text { Struktur spesifik: } \\
\text { stolon,rhizoid,foot } \\
\text { ceel/sel kaki }\end{array}$ & Rhizoid \\
\hline
\end{tabular}

Pengamatan pada kelompok II diambil salah satu kontaminan dari ke 3 botol dan dilakukan pengamatan pada mikroskop maka deskripsi yang ditujukan termasuk kelas Zigomycetes (Susilowati dan Listyawati, 2001) oleh karena warna sporangium berwarna putih, miselium terang dan berwarna, memproduksi spora, kemudian hifanya tidak bersekat/non septa, tangkai spora sederhana dan ada rhizoid. Dari pengamatan deskripsi pada kelompok II termasuk ciri deskripsi dari Mucor

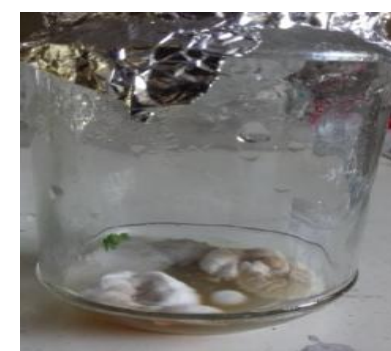

Gambar 2. Hasil pengamatan kontaminan pada Kelompok II.

Pada pengamatan kelompok III diperoleh bahwa secara umum mempunyai ciri morfologi yang sama antara lain pada hari 1 dan hari ke 2, untuk botol 1,2 dan 3 media belum terkontaminasi, hari ke 3 pada botol 1 terdapat benang putih pada eksplan, botol 2 semakin besar benang putih pada eksplan, botol 3 terdapat benang putih pada ekplan dan media, hari ke 4 pada botol 1 koloni berwarna hijau, botol 2 koloni berwarna hijau kebiruan pada eksplan, botol 3 koloni berwarna hijau pada media, hari ke 5 pada botol 1 koloni sudah mulai lebih besar, botol 2 dan botol 3 koloni sudah mulai besar dan ada benang halus pada eksplan, hari ke 6 untuk botol 1 koloni mulai menutupi eksplan dan media, botol 2 dan 3 koloni berwarna coklat dan menutupi eksplan dan media, hari ke 7 pada botol 1, 2 dan 3 koloni berwarna kecoklatan dan menutupi botol kultur.

Tabel 3. PengamatanMikroskop pada Kelompok III dari Pengamatan Morfologi yang Sama

\begin{tabular}{|ll|c|}
\hline \multicolumn{2}{|c|}{ Hasil Deskripsi } \\
\hline \multicolumn{2}{|c|}{ Ciri-Ciri Morfologi } & Kontaminan \\
\hline 1. & Warna sporangium & $\begin{array}{c}\text { Putih, coklat } \\
\text { kehitaman }\end{array}$ \\
\hline 2. & $\begin{array}{l}\text { Miselium terang } \\
\text { atau keruh }\end{array}$ & Terang \\
\hline 3. & $\begin{array}{l}\text { Miselium berwarna } \\
\text { atau tidak }\end{array}$ & Ada spora \\
\hline 4. & Memproduksi spora \\
\hline 5. & $\begin{array}{l}\text { Hifa bersekat atau } \\
\text { tidak bersekat }\end{array}$ & Tidak bersekat \\
\hline 6. & $\begin{array}{l}\text { Tangkai } \\
\text { sederhana atau } \\
\text { bercabang }\end{array}$ & Sederhana \\
\hline 7. & $\begin{array}{l}\text { Struktur } \\
\text { spesifik:stolon,rhizoi } \\
\text { d,foot ceel/sel kaki }\end{array}$ & Foot ceel/sel kaki \\
\hline
\end{tabular}


Berdasarkan pengamatan pada kelompok III dan pengamatan yang dilakukan pada mikroskop maka deskripsi yang ditujukan termasuk kelas Deuteromycetes (Waluyo, 2004) oleh karena warna sporangium putih, coklat kehitaman, miselium terang dan berwarna kemudian memproduksi spora, bersepta, tangkai spora sederhana, terdapat sel kaki. Ciri deskripsi Kontaminan yang ditemukan pada kelompok III adalah Aspergillus.
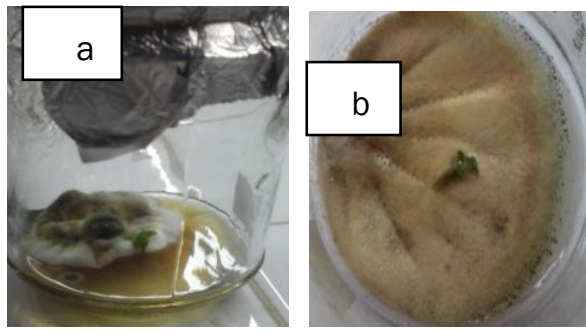

Gambar 3. Hasil pengamatan kontaminan pada kelompok III (a) dalam botol kultur difoto dari samping (b) difoto dari bagian atas

Pengamatan pada kelompok IV pada hari 1 , hari ke 2 pada botol 1,2 dan 3 tidak terkontaminasi dan hari ke 3 pada botol 1 muncul titik-titik berwarna putih pada eksplan C. roseus, botol 2 terdapat ada titik-titik berwarna putih, botol 3 muncul titik berwarna putih, hari ke 4 pada botol 1 titik berwarna putih mulai besar, botol 2 dan 3 titik-titik berwarna putih mulai besar pada eksplan, hari ke 5 pada botol 1 permukaan berlendir dan berwarna putih, botol 2 permukaan berlendir dan berwarna putih pada pinggiran botol, hari ke 6 pada botol 1,2, dan botol 3 permukaan berlendir dan berwarna putih, licin, hari ke 7 pada botol 1, 2 dan botol 3 permukaan berlendir dan berwarna putih, licin dan timbul pada media.

Tabel 4. Pengamatan Mikroskop Kontaminan Kelompok IV dari Pengamatan Morfologi yang Sama.

\begin{tabular}{|c|c|}
\hline \multicolumn{2}{|c|}{ Hasil Deskripsi } \\
\hline Ciri-Ciri Morfologi & Kontaminan \\
\hline 1. Warna koloni & Bening \\
\hline 2. Permukaan koloni & Licin/berair \\
\hline $\begin{array}{l}\text { 3. Miselium berwarna } \\
\text { atau tidak }\end{array}$ & Tidak \\
\hline 4. Memproduksi spora & Tidak \\
\hline $\begin{array}{l}\text { 5. Hifa bersepta atau } \\
\text { non septa }\end{array}$ & Tidak \\
\hline $\begin{array}{llr}\text { 6. } & \text { Tangkai } & \text { spora } \\
\text { sederhana } & \text { atau } \\
\text { bercabang } & \end{array}$ & Tidak \\
\hline $\begin{array}{l}\text { 7. Struktur spesifik: } \\
\text { stolon,rhizoid,foot } \\
\text { ceel/sel kaki }\end{array}$ & Tidak \\
\hline
\end{tabular}

Pengamatan yang dilakukan pada kelompok IV (Gambar 4) kemudian diambil salah satu kontaminan dari ke 3 botol yang terkontaminasi dan diamati pada mikroskop menujukkan ciri deskripsi termasuk kelas Ascomycetes (Susilowati dan Listyawati, 2001) karena warna koloninya berwarna putih, permukaan koloni licin, miselium tidak berwarna, tidak memproduksi spora, tidak berhifa, tidak memiliki tangkai spora, kemudian satu sel. Deskripsi tersebut Menurut Alexopoulos \& Mims (1979) termasuk ciri deskripsi dari Sacharomyces.
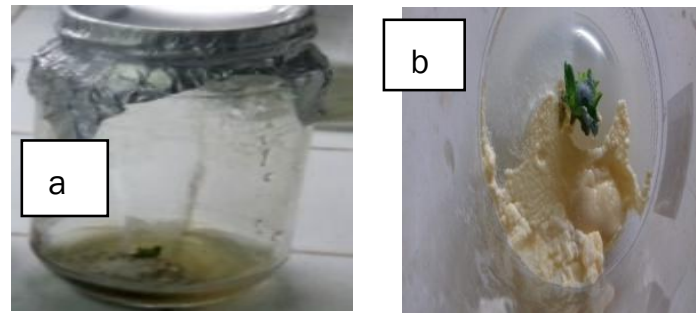

Gambar 4. Hasil pengamatan kontaminan pada kelompok IV (a) dalam botol kultur difoto darii samping (b) difoto dari bagian atas

Berdasarkan hasil pengamatan sebagian besar berupa jamur berhifa dan jamur lendir dan tidak didapatkan kontaminan bakteri. Sedangkan menurut Rumengan, (2001) bahwa bakteri dapat diidentifikasi dari media kultur di laboratorium Bioteknologi pertanian. Demikian juga Pandiangan, (2003) bahwa kontaminan pada media kultur kalus sering juga ditemukan bakteri dengan menggunakan media MS. Namun pada penelitian ini tidak ada ditemukan bakteri yang mengkontaminasi. Setiap kondisi kultur terkontaminasi sangat ditentukan oleh keahlian pelaksananya, sterilnya lingkungan kerja, jenis eksplannya, cara sterilisasinya, kondisi suhu dan iklim pada saat kultur (Pandiangan, 2009).

Penelitian ini menemukan kontaminannya umumnya kelompok jamur. Ada kemungkinan karena saat kultur musim penghujan dan sedang banyak media kontaminasi dengan jamur dari penelitian orang lain juga dalam laboratorium yang sama. Proses pembuatan kultur jaringan, komponen yang paling rentan terhadap kontaminasi mikroorganisme adalah media tumbuh dan eksplan. Gunawan (1988) mengatakan bahwa media kultur jaringan merupakan media yang sangat mendukung bagi mikroba. Mikroba tersebut tumbuh dengan cepat dan akan menutupi permukaan media dan eksplan yang ditanam. Disamping itu, mikroba akan menyerang eksplan melalui luka-luka akibat pemotongan dan penanganan waktu sterilisasi sehingga mengakibatkan kematian jaringan eksplan

Menurut Waluyo (2004) mikroorganisme membutuhkan nutrien untuk kelangsungan hidupnya yang berperan sebagai sumber energi dan bahan pembangun sel. Bahan makanan yang diperlukan adalah air, sumber energi, sumber karbon, sumber mineral, dan nitrogen. Kebutuhan 
akan zat-zat nutrisi bervariasi dari setiap mikroorganisme.

Hasil penelitian menunjukkan mikroba yang tumbuhpada tiap-tiap medium sama walaupun eksplan berbeda. Salah satu penyebabnya adalah media kultur jaringan yang digunakan adalah sama yaitu medium MS (Murashige dan Skoog) dan kondisi lingkungan kultur, cara kerja dan keahlian pelaksananya sama. Komposisi medium ini tentunya sama, yang cocok untuk pertumbuhan mikroba tersebut.

\section{Kesimpulan}

Berdasarkan penelitian yang telah dilakukan terdapat sembilan jenis burung yang ditemukan adalah: Butorides striatus, Collocalia esculenta, Passer montanus, Pycnonotus aurigaster, Geopelia striata, Gallirallus torquatus, Hirundo tahitica, Nectarinia jugularis, dan Halcyon chloris. Indeks keanekaragaman burung termasuk dalam kategori sedang melimpah.

\section{Daftar Pustaka}

Alikodra, H. S. 1980. Dasar-Dasar Pembinaan Margasatwa. Fakultas Kehutanan Institut Pertanian Bogor, Bogor.

Coates, B. J and D, Bishop. 2000. Panduan Lapangan Burung- Burung di Kawasan Wallaceae (Sulawesi, Maluku dan Nusa Tenggara, Indonesia). Penerbit Birdlife, Bogor.

Fachrul, F. M. 2007. Metode Sampling Bioekologi. Bumi Askara, Jakarta.

Holmes, D and K, Phillips. 1999. Burung-Burung di Sulawesi. Puslitbang Biologi-LPI, Jakarta.

Howes, J., D, Bakewell and Y. R, Noor. 2003. Panduan Studi Burung Pantai. Wetlands Internasional, Bogor.

Jarulis. 2005. Fauna Burung di Taman Kota dan Jalur Hijau Kota Padang. Jurnal Gradien. 1(2): 98-104.

Kinnaird, F. Margareth, 1997. Sulawesi Utara: Sebuah Panduan Sejarah Alam. Yayasan Pengembangan Wallace, Indonesia.

Lee, R. J., J, Riley., R, Merrill and R. P, Manoppo. 2001. Keanekaragaman Hayati dan Konservasi di Sulawesi Bagian Utara. WCS IP Sulawesi, Departemen Kehutanan (PKA) dan natural Resources management Progam, Manado.

Mackinnon, J., K, Philips and B. B, Van. 2010. Burung-burung di Sumatra, Jawa, Bali, dan Kalimantan. Bogor: Pustlitbang BiologiLIPI/Birdlife, Indonesia.

Syafrudin, D. 2011. Keanekaragaman Jenis Burung Pada Beberapa Tipe Habitat di Tambling Wildlife Nature Conservation (Twnc), Taman Nasional Bukit Barisan Selatan Lampung [skripsi]. Departemen Konservasi Sumber Daya Hutan dan Ekowisata Fakultas Kehutanan Institut Pertanian Bogor, Bogor.

Widodo, 2009. Komparasi Keragaman Jenis BurungBurung di Taman Nasional Baluran dan Alas Purwo pada Beberapa Tipe Habitat. Berk, Panel, Hayati. 14:113-124.

Yayuk, W., 2013. Keanekaragaman Jenis Burung Diural dalam Kawasan Cagar Alam Mandor Kabupaten Landak. 